\title{
Roberto Rossellini presents
}

Book or Report Section

Accepted Version

O'Brien, A. (2017) Roberto Rossellini presents. In: Gibbs, J. and Pye, D. (eds.) The Long Take: Critical Approaches. Palgrave Close Readings in Film and Television. Palgrave Macmillan, London, pp. 117-132. ISBN 9781137585721 Available at https://centaur.reading.ac.uk/67421/

It is advisable to refer to the publisher's version if you intend to cite from the work. See Guidance on citing.

Publisher: Palgrave Macmillan

All outputs in CentAUR are protected by Intellectual Property Rights law, including copyright law. Copyright and IPR is retained by the creators or other copyright holders. Terms and conditions for use of this material are defined in the End User Agreement.

www.reading.ac.uk/centaur

\section{CentAUR}

Central Archive at the University of Reading

Reading's research outputs online 


\section{Roberto Rossellini Presents}

Roberto Rossellini's history films (made, in fact, for television) include Socrate (1970), Blaise Pascal (1971), Cosimo de’ Medici (1972) and Cartesius (1973), and are known for certain historiographical and cinematic techniques. These include an unapologetic focus on "great men," a sustained attention to material objects and processes, an avoidance of expressive performance, and a tendency to use sequence shots which are aided and enriched by a mechanical zoom. La Prise de pouvoir par Louis XIV (1966) answers to all of these, and is probably the most widely written about of the series. But the more it comes to represent a body of work and a filmmaking methodology the third chapter of Rossellini's career, following neorealism and melodrama the more likely we are to lose sight of the film's own complexities and mysteries, which are considerable. It is understandable (and often useful) to think of the history films as being guided by a consistent ambition, but this essay seeks to explore how and why the long take matters particularly in $L a$ Prise de pouvoir; why it matters in a film about a man who comes to power by way of spectacle.

In his critical biography of Roberto Rossellini, Tag Gallagher characterizes the camera's sensibility in La Prise de pouvoir through a comparison with the work of Max Ophüls:

'Looking critically' - one of Roberto's definitions of neo-realism posits the camera as a tool of inquiry. Rossellini never spoke of the camera as Bazin did, as a means of recording; for Rossellini it was a 'microscope', 'an instrument of torture', an aggressive rather than a passive instrument. No filmmaker ever used it as he did. He does not 'present'. He does not allow events to speak for themselves. Instead he perpetually attacks them, moving in and out, trying to get closer to this or that. Ophüls is always moving, too; but Ophüls's motions 'present' his events and become in turn the rhythms of the movie and its characters' lives. Rossellini's camera, in contrast, does not comment or analyse; indeed it seldom expresses, narrates, or even follows an event. Instead, it inquires; instead, it perpetually intrudes into an event. (Gallagher, 1998, pp. 577-578) 
Gallagher certainly manages to communicate the unusual sense of perpetual inquiry we feel in La Prise de pouvoir, but I believe he underestimates the film's internal variety. For a film which, on first viewing, seems to have a rigorously monotonal design, La Prise de pouvoir in fact moves quite deftly between contrasting (if not contradictory) long-take effects. In this essay I hope to elucidate those variations, and to explore their particular resonance within the film's story world. In doing so, I hope to avoid the temptation of trying to define an overriding - and insufficiently precise - long-take aesthetic or camera temperament.

Writing with clarity and validity about the nature and purpose of a camera's activity (recording, exploring, following, witnessing, judging, displaying, omitting, etc.) is of course one of the fundamental challenges of film theory and criticism, and a challenge which perhaps becomes more acute in the face of the long take - a technique which offers us, as an audience, the opportunity to reflect on, and even choose between, such behavioural models, in the process of watching. As a shot exhausts its basic information-giving purpose, we are obliged to consider what requires and motivates the film to still be showing us the current passage of action or inaction. I will try to show that, in La Prise de pouvoir, possible answers to this question come and go as the film develops; its long takes are not beholden to a singularly motivated vision.

However, we can nevertheless follow Tag Gallagher's general direction, and begin with the uncontroversial claim that, in La Prise de pouvoir, Rossellini's camera maintains an unusual rhetorical relationship between filmmaker and subject matter. Part of this effect is surely traceable to the fact that the director made the film as a didactic, educational tool (a mode or spirit we are not accustomed to dealing with in the canon of long-take stylists). Also, the almost otherworldly rituals of the $17^{\text {th }}$-century French court are filmed with a remote-controlled zoom lens, an anachronism which seems to assert with particular deliberateness the mediating presence of the filmmaker as historian (but one which, in theory, should not be any more troubling than seeing biblical Rome in Cinemascope). Yes, the technical execution of this film, as with Rossellini's other history films, seems to emerge from important 
historiographical principles. However, the central claim I wish to develop is that the camera's 'behaviour' in La Prise de pouvoir must be understood in the context of a particular (diegetic) social environment, one characterized by an unusually strong emphasis on presentational dynamics. What appeared to John Hughes (in a very rich critical engagement with Rossellini's history films) like "terrifying objectivity" is, I will argue, something more sensitively attuned to the story world Rossellini explores (Hughes, 1974, p.17).

\section{Treating Mazarin}

The film's first long take does not actually feature Louis XIV at all, but instead it studies the activity surrounding the soon-to-be-deceased Cardinal Mazarin, France's (and possibly Europe's) most powerful man. Specialist doctors have visited his chamber, examined his sweat and urine, and have decided - in consultation with the Cardinal's 'right hand man', Jean-Baptiste Colbert - to have him bled. Throughout the shot, the camera's position in space remains almost entirely consistent; facing the chamber's door and bed, it sits at a small but discernible distance from the movement of bodies, and no character looks to the left or right of the camera, nor moves from or to the space behind it. We thus seem not to be in a scene, but scanning it (through repeated panning left and right) at one remove. More significant than the cumulative effect of such scanning, though, is the more precise question of what spheres of action the camera moves between, and quite what the long take does to those situations.

Once the Cardinal (César Silvagni) has been carried from his bed to sit for his operation in a chair (in a position that can best be described as downstage right), a small group gathers around his sprawling, limp body, and the film momentarily chances upon an arresting painterly composition. The Cardinal fills the left hand side of the frame, draped in a nightdress whose whiteness starkly offsets the black attire off those surrounding him, his eyes lightly closed, his face perfectly illuminated by a mysterious light from above. Whose doing is this? The Cardinal has certainly not staged the scene for the purpose of any visitors, and no person in the room is in a position to witness this startling spectacle. The camera itself seems to have been caught 
unawares, and has to zoom slightly (often an index of unpreparedness) to achieve the appropriate framing. To that extent, this is a film image like so many others, a visually pleasing arrangement with no discernible motivation other than the rhythms of the drama. However, the Cardinal is a man to whom everyone in the room is obliged to pay physical deference, and it is hard not to interpret the camera's aesthetic recognition of his eminence with this in mind, as if it is somehow acknowledging the Cardinal. The physical arrangement has an almost overwhelming presentational quality, but the presentation feels utterly native to the environment, the procedure one in which all visible characters are absorbed.

And then, just as the blade is about to be applied to Cardinal Mazarin, the camera follows the movement of two doctors as they walk away from the operation toward the other side of the room, soon to be joined by Colbert (Raymond Jourdan). The pan is not abrupt or jarring, and is in fact fluently motivated by the doctors' movement. But one crucial consequence is that we are now decisively not looking at the Cardinal at the moment of incision. A faint, squeamish cry prompts Colbert to anxiously look back in the direction of Mazarin, but the camera does not follow his glance. (This is one of the only moments in the film to fully activate offscreen space.) $)^{i}$ The camera has chosen not to retain Mazarin as its chief concern. The subsequent "backstage" conversation between Colbert and the doctors, a relatively frank and private exchange about the blood-letting procedure, then marks a shift from the theatrically choreographed operation - but not a stark shift. The expectations of strict propriety still seem to govern the tone and manner of everyone's behaviour, and the framing continues to be characterized by a strong sense of order (three identically dressed male figures each occupying a third of the frame). If the initial pan to the right had suggested the potential of the camera to transcend the restrictions of self-conscious court ritualism, it actually finds yet another version of that same face.

Shortly after the candid discussion, a reverse pan, following the doctors back towards Mazarin, restores the original painterly composition (in a slightly altered state), and the doctor rather ostentatiously professes his dedication to the cause of restoring Mazarin's health. Had Rossellini cut between two 
different set ups - the Cardinal's death pose and the doctors' private exchange with Colbert - the emphasis would surely have fallen on the distinction between a mode of courtly presentation and a "mechanics-ofpower" perspective. Instead, the camera follows the movement of the doctors from one sphere to the next, and finds in each an element of selfconsciousness and an element of happenstance. Moments of theatrical presentation crystallize, but they do not calcify. Pageantry cannot really be distinguished with any confidence from other modes of behaviour.

In the context of the film's narrative, it is interesting that France's most powerful current figure (soon to be replaced by Louis XIV) is introduced in such a way that places him beyond the expectations of appearance - a frail and vulnerable man with nothing left to prove to the world, and no strong or apparent motivation to exhibit himself in a particular manner. (Just before receiving the King, Mazarin will apply makeup to his face, but there is no discernible change in his appearance; the moment is one of pathos more than of performance.) The Cardinal's character and body are of course watched with due deference by those in attendance, but even though Mazarin retains some awareness of how he appears to others, there is no requirement for him to generate, consolidate or display power through performance. This will instead be the challenge for the King.

\section{Absorbed in theatre}

The title of this essay is a response to Tag Gallagher's assertion, in the passage quoted above, that Rossellini "does not 'present'." For while Gallagher equates presentation with allowing "events to speak for themselves," I find La Prise de pouvoir to be a film about the fact that presentation is anything but neutral and disinterested. It is centred on a man whose life allowed him virtually no opportunity to avoid or resist the necessity of sustaining certain modes of appearance, and indeed one for whom selfpresentation became (or becomes, throughout the film) a mode of selfpreservation. Perhaps the crucial distinguishing feature of Rossellini's film about Louis XIV is that it does not attempt to see the man behind the spectacle. It accepts the spectacle as a legitimate and important part of the 
history. Without uncritically rehearsing the pomp of Versailles and all its theatrical appendages, La Prise de pouvoir manages to retain a strong sense of the King's - and the court's - culture of presentation. It takes seriously the strange process by which a man of unremarkable appearance and no apparent charisma is obliged to become the centre of everything, a being of cosmic force. What is the use of trying to look beyond or beneath this, Rossellini seems to ask, when the phenomenon of presentation itself is so vital?

One way of trying to better articulate Rossellini's interrogation of presentation is by turning to the influential model of absorption and theatricality developed by art critic and historian Michael Fried, and occasionally taken up by writers on film. Fried meticulously and imaginatively traces a tradition in French painting form the $18^{\text {th }}$ to the $19^{\text {th }}$ century in which a tension is played out between absorptive images (those that depict and induce absorption) and theatrical images, which Fried sees as relying too heavily on the presence of a viewer for their affirmation. Richard Rushton has helpfully transposed Fried's model for cinema, describing how classical narrative cinema can be understood as an absorptive mode which never quite overcomes theatricality: "The mode of viewing in the classical cinema is ... one which establishes a tense dialectic between the spectator's seeking of the film, that is, the spectator's absorptive pull into the film, and the film's seeking of the spectator, the film's attempt to 'present' itself to the spectator, in other words, its theatricality" (Rushton, 2004, p.234). As Rushton tells it, modernist cinema is based on an even more tense dialectic, an irresolvable tension, between absorption and theatricality - a "double bind" closely related to the effects Fried identifies in the seminally modernist painting of Édouard Manet. Many modernist filmmakers have of course experimented with that tension (Rushton's key example here is Jean-Luc Godard), but few films can be said to have a narrative premise and diegetic setting so suited to that tension as $L a$ Prise de pouvoir.

How and why might the long take be used to absorptive or theatrical ends? Does it draw us in or beg to be admired? Are its character-subjects absorbed in their own processes of contemplation and inter-subjectivity, or do 
they appear before us in the long take more as exhibits, arranged and directed expressly for a spectator? Of course, the long take can at a given moment in a given film achieve variations on all these effects. What makes $\mathrm{La}$ Prise de pouvoir so fascinating in the context of such terms is that its characters are absorbed in theatrical behaviour. The conditions of the royal court make it very difficult for us to distinguish between (for example) theatrical visual compositions and a "natural" mise-en-scène based on gestures and arrangements which grow out of the film's setting. Michael Fried's example, on which Rushton builds, of Manet's barmaid (in 'A Bar at the Folies-Bergère') as fundamentally caught between absorption and theatricality, is based on the critic's attentiveness to the conditions of the setting, and the relative plausibility of the encounter (between the viewer and the barmaid) upon which the painting is founded. As with Rossellini's film, here is a setting in which a person might naturally and normally stand before us, in a proscenium arrangement.

I will not attempt to forcefully apply Fried's interpretive model to $L a$ Prise de pouvoir, but it is at least useful to remark that questions of presentation, theatricality and absorption tend to inform critical writing on the film. William Guynn describes the mode of La Prise de pouvoir as presentational (2006, p.93); James Roy MacBean describes it as one split between a bourgeois concern with things and an aristocratic concern with appearances (1971, p.27); Martin Walsh tries to capture the film's unusual contract with its viewer in the following terms: "Once inside, we never leave but are condemned to orbit Louis' domain, just like the inhabitants of the court themselves. The extraordinary thing about it, though, is that our absorption is both allowed and interrogated" (1977). To what extent can Rossellini's deployment of the long take be said to "allow and interrogate" absorption and theatricality? And why does such an approach accrue particular meaning in the context of King Louis's court? 


\section{The King and Colbert}

King Louis XIV (Jean-Marie Patte) is not introduced to us by way of a long take, and the monarch's evident incapacity for holding the gaze of others is in fact one of the key characteristics of his first scene in the film. Woken by the entry of court members into the Queen's private chamber, where he has spent the night, the King is obliged to recite prayers to the gathered audience, who line the wall facing his bed. The cuts on the axis back and forth between a fumbling, embarrassed king and an expressionless group of onlookers have a comic quality (Wes Anderson has expressed his admiration for this film). The situation is theatrical - the King and Queen, as performers, are framed by the bedposts and drapery - but the cutting between the King and his audience ensures that we feel Louis's failure in this sense; the camera is not held by his performance, and instead the King's unease is made palpable.

The scene which comes closest to illustrating the taking of power, the assumption of authority so acutely lacking in the King's first appearance, is a startlingly simple one. Immediately after the death of Cardinal Mazarin, Louis orders a meeting of his council at the Louvre palace, at which he asserts to his ministers that he now intends to exert authority directly. The King arrives, stands at the head of the council table, issues his instructions, turns, and leaves. Previously he has been shown as unsure of his physical presence; cramped behind furniture or furnishings, turning his back on others, walking one way and then walking back on himself. In such moments the long take tends to exert a pressure on Louis, its gaze roughly equivalent to that of a court attendant politely but rigorously watching a man slightly out of his depth (these are the sequences which most closely follow Gallagher's description of Rossellini's camera as something of a hostile agent). The council meeting, however, represents a shift in the film's long-take strategies. Now, a sustained shot length begins to seem more complicit in the King's project; as he holds his body almost entirely motionless, his eyes cast mainly away from the ministers, the camera similarly look and looks, refusing to indulge any interpersonal dynamics among the members of council, details which would only distract from or confuse this performative declaration of absolute authority. 
The premise of this scene has a certain irony; the King wishes to present himself as a ruler whose authority does not merely reside in regal presentation. The execution of the long take reinforces the matter-of-factness for which Louis is presumably striving. This is partly achieved by the positioning of the camera at the far end of the table, framing the King at roughly 45 degrees on the right-hand edge of the frame, while his councillors are bunched in a long line to one side of the table. Gone is the frontal framing of the King's first scene, which seemed to generate an unwelcome (for the King) theatricality. There is still, of course, an audience, but this is one which Louis is not obliged to face. And by holding within a single frame the King and his council, by emphasizing that they are present to him, unable to claim the film's attention on their own terms, Rossellini has surely helped render the councillors subservient. The long take in this scene is calibrated to the King's performance.

Following the council assembly, the King moves immediately to a private meeting with Colbert, in which the two men establish their working relationship by engaging in a relatively frank conversation about financial stability, and potential threats to monarchical authority. Gestures of uncertainty now return to Louis - he paces, avoids Colbert's gaze, restlessly moves his hands about his midriff - and we once again seem to be privy to the King's considerable imperfections. But whereas the King had previously been under the watchful eye of witnesses we know, or suspect, to be unsympathetic in their appraisal of him, the meeting with Colbert is an opportunity for Louis to "try out" his new found authority in relative security. Colbert holds a steady position in the room (and the frame) as an attentive and responsive confidant, and as the King positions and re-positions himself around Colbert, eventually settling into an appropriately regal station at the table, it becomes clear that Colbert has been the anchor of this scene. Standing for the most part opposite the camera, looking across to or down towards the King, Colbert's physical position is twinned with the camera's, and his temperament - observant but not awestruck - becomes our way of seeing the King. (MacBean writes of Rossellini's "cautious, alert distance" from his historical subject matter; the phrase could similarly describe Colbert (1971, p.21).) Louis becomes increasingly assured in his manner, and by the end 
has taken up a position of confident authority very similar to that which he enjoyed in the previous scene; looking ahead, off-screen left, issuing instructions.

The cinematography and choreography of these two consecutive scenes share important qualities, but that is not to say that they are determined by a fixed aesthetic. However tempted we may be to characterize Rossellini's camera as a removed observer, it is important to remember that a shot's meaning emerges not only from the manner of its camera; indeed, that manner cannot be properly understood in isolation from the nature and contents of the filmed drama.

\section{Versailles}

Dining at Versailles, the King sits alone at the centre of a long table, flanked by a large retinue of aides. The table is not as lavishly populated as we might expect - two candelabras, and only the plates from which Louis picks at his small portions - perhaps in an effort to ensure the King's absolute visibility to those in attendance. (As La Prise de pouvoir develops, there is an increasing emphasis on his obsessive attention to sartorial detail, and so every reason to assume that Louis cares deeply about such matters.) The self-conscious carrying-out of a daily routine invites us to think back to those moments in the Queen's bed chamber, when Louis was the uncomfortable performer in front of an obsequious-cum-intrusive audience. Now, the film makes clear that the King has mastered such dynamics for his own ends, and it does so through the most forcefully choreographed shot in the film.i

Shortly after requesting bread, the King turns to a nearby attendant to request music; this man in turn relays the order to another, just a few feet away. All carried out within the space of a single, medium-long-shot, it is a rather straightforward rendition of court custom and hierarchical procedure taken to an absurd degree. This, however, is only the introduction to a much more complex long take. As the second man moves to carry out his task and despatch the message to the musicians (whom we cannot see), he moves away from the King and towards the camera, but remains facing the King, 
bowing repeatedly. As he does so, the camera begins to crane backwards, essentially tracing the man's movements towards the opposite end of the room, and in the process revealing a large, deep crowd of silent and static aristocrats, gathered to witness the King's meal. What we might have initially taken to be a privileged view of a private or exclusive event (dinner) is playfully revealed, through the crane-shot "surprise," to be a spectacle of which the King is fully in control. It is perhaps the only visual surprise in $\mathrm{La}$ Prise de pouvoir.

In the Queen's chamber, Louis had been caught unawares; we saw the members of the court enter before he had even woken up, and visual emphasis was given to their intimidating collective as a kind of twodimensional, oppositional block of faces. Now, Louis is in a fundamentally different position, and the execution of the long take makes that vivid to us. Significantly, the camera does not turn its direction away from the King, even as it recedes into the depths of the large audience and Louis is lost to the far background. The camera, like all the other onlookers here, must look towards the King.iii The rigidity of the physical and verbal performances in this scene, and the patent absurdity of the actions being carried out, should not fool us into thinking that La Prise de pouvoir has necessarily achieved (or has sought) a critical distance from the historical events. The long take here is not ironic. Louis XIV designed Versailles, the building and the culture, to dazzle and immobilize the French nobility, and render it unable to function properly from a critical and autonomous vantage point. When the camera tracks back from Louis's table, and becomes subsumed in the crowd, losing its own vantage point on the King, the moment must surely register as a perverse victory for the film's protagonist over its audience. We can no longer look as inquisitively or as probingly at the King; we seem to have been absorbed into a different manner of watching.

No account of this moment can overlook the crucial difference between a craning motion and a zoom. When Tag Gallagher writes of Rossellini's camera perpetually intruding into an event, he seems to have in mind the forward zoom, which is used in much of La Prise de pouvoir. The zoom is often thought of as an obstacle to absorption, an unwelcome reminder of the 
camera's primal separation from profilmic activity; in the case of Rossellini's history films, this removal tends to be read, more generously, as evidence of the director's restless curiosity about his subject matter, what Vivian Sobchack calls "transformation wrought by the activity of attention" (1990, p.28). It is as if writing, staging and recording is not enough for Rossellini; the filmmaker still wants to probe, and is willing to concede to his audience that the dramatic reconstruction is not a world viewed, and cannot be left alone to speak for itself. "Rossellini's zooms preserve the wholeness of an event, yet, at the same time, are separate from that event, becoming a consciousness viewing that event" (John Belton, 1980, p.22).

This way of reading is valid up to a point, but once again allows little opportunity for careful distinctions within, and between, the history films. A slightly modified interpretation of the zoom in La Prise de pouvoir would return to the idea of the camera as a socialized observer; I have more than once equated its stillness and immobility with a kind of courtly deference, and following these terms, the zoom could be understood as a relatively improper exercise of attention. A customary physical distance from the King is retained, but the zooms speak of a spectatorial desire to push those boundaries, and to look a little more (a little too) eagerly. Had the camera in these scenes moved at will, towards and away from the King and his courtiers, the tension would be lost, the audience would be too secure in its knowledge that Rossellini's access is unlimited. The zoom maintains a crucial doubt on this point; as these men go to great lengths to present themselves, is the camera with them and watching on, somehow constrained and motivated by diegetic conditions, or scrutinising the action more freely at one remove? Is it the view of an absorbed witness or a critical historian? Either way, a climactic long take in which the camera physically retreats from the King's dining stage gives rise to a strange and significant shift.

Unlike almost every sequence preceding it, the length of this shot is not determined by an interest in what is currently transpiring (such as a conversation or a practical routine), and is instead tied to the movement of a character. We move through space in a way which is unique in La Prise de pouvoir. And we track the movement not of the King, but an anonymous 
attendant. Here, we might pick up Gallagher's passing comparison of Rossellini with Ophüls, and recall those moments in Letter From an Unknown Woman (1948) and Madame De... (1953) (for example) in which the director momentarily draws our attention to those peripheral figures (musicians, butlers, etcetera) sustaining the lavish theatre of the main attraction. The tracking shot in Louis's dining hall does something quite different, however. This man's movement across a crowded room has been ordered by the King as part of a theatrical display; he is the only person moving, and walks against the grain of the gathered crowd, all of whom face the King. The action is not furtively or independently observed by the camera, as we sometimes sense in the zoom-based sequences. Here, as we move further and further away from the King's immediate vicinity, but in a direction and manner which are absolutely determined by his whims, the audience of La Prise de pouvoir are more compliant with his theatre than at any moment during which we observe him directly.

By the end of the film, Rossellini's camera will return to its more customary "alert distance." The final shot has the King alone (for the first time), reading to himself; a quintessential gesture of absorption. We slowly zoom in, as Louis reads aloud, in the film's final spoken words, "neither the sun nor death can be gazed upon fixedly." For all the persistence with which La Prise de pouvoir looks at its central character, the film's gaze can never been understood as fixed. It is too contingent on the design and drama of different moments, moments fraught with uncertainty about what is present to us and what is presented to us. 


\section{Works cited}

J. Belton (1980) 'The Bionic Eye: Zoom Esthetics', Cineaste, 11: 1.

D. Forgacs (2011) 'Rossellini’s Pictorial Histories', Film Quarterly, 64: 3.

T. Gallagher (1998) The Adventures of Roberto Rossellini: His Life and Films (New York: Da Capo Press).

W. Guynn (2006) Writing History on Film (New York; London: Routledge).

J. Hughes (1974) 'Recent Rossellini', Film Comment, 10: 4.

J. R. MacBean (1971) 'Rossellini's Materialist Mise-en-Scène of La Prise de pouvoir par Louis XIV, Film Quarterly, 25: 2.

R. Rushton (2004) 'Early, Classical and Modern Cinema: Absorption and Theatricality', Screen, 45: 3.

V. Sobchack (1990) 'The Active Eye: A Phenomenology of Cinematic Vision', Quarterly Review of Film and Video, 12: 3.

1

\footnotetext{
' David Forgacs cites the absence of offscreen space as one of the chief characteristics of Rossellini's "neoprimitivist" style in the history films (2011, p.31).

ii This scene is widely reported to have been directed by Renzino Rossellini, Roberto's son.

iii In his study of visual representations of Louis XIV's reign, Peter Burke notes that it was forbidden to turn one's back even on certain paintings of the King (1994, p.9).
} 